\title{
Die kommunikasiekrag van liturgiese simbole met spesifieke verwysing na die toga
}

\author{
P J Roets \& T F J Dreyer \\ Departement Praktiese Teologie (Afd A) \\ Universiteit van Pretoria
}

\begin{abstract}
The communication of liturgical symbols with specific reference to the robe

Recently, in the name of renewal, full churches and the satisfaction of church members, the hunting season was opened on many of the church's traditional symbols. Renewal is necessary, but before a welltrusted custom is thrown overboard, the value of such a custom must first be established. A well-tried practice usually is worth more than what can be seen on the surface at first glance. Liturgical symbols, amongst others the robe, are being put under suspicion by many church members as well as theologians. Do these liturgical symbols impede the communication of the word of God or does the robe, inter alia, contribute to the communication of the Gospel, which is the nucleus of protestant public worship? By means of empirical research, this article aims to establish the theological meaning and function of the robe as a liturgical symbol.
\end{abstract}

\section{INLEIDING}

By ' $n$ onlangse geleentheid het ' $n$ bekende professor van die Nederduitsch Gereformeerde Kerk 'n interessantheid beleef. 'n Vriend van hom, wat destyds met groot stem ten gunste was van die afskaffing van ampsdrag in die Nederduitsch Gereformeerde Kerk, het hom gevra om sy dogter te trou. 'Maar, ek wil 'n spesiale guns vra' het die leraar se vriend gesê: 'Trek asseblief vir die geleentheid jou toga aan. Dit is ons enigste dogter en ons wil haar troue so "perfek" as moontlik hê!' Die professor het by homself gedink: 'As "perfek" by 'n troue 'n toga beteken, wat dan van 'n erediens in die kerk?' (Die Kerkbode 1997:10).

* Hierdie artikel is 'n verwerking van die resultate van 'n BD-skripsie, ingedien en anvaar as deel van die vereistes vir die BD-graad (1997), Departement Praktiese Teologie (Afd A), Universiteit van Pretoria, onder leiding van prof dr T F J Dreyer. Die resultate van hierdie studie word in twee opeenvolgende artikels, wasrvan hierdie artikel die cerste is, gepubliseer. 
Gereeld word stemme gehoor van die noodsaaklikheid van verandering en vernuwing. Die woord vernuwing het 'n populêre woord geword, wat almal wil gebruik en implementeer. Vernuwing is vir die kerk ook belangrik, in die lig daarvan dat die gemeentelid se waardes met verloop van tyd self verander. Vernuwing in die kerk is dus noodsaaklik, maar voordat 'n beproefde gebruik in die naam van verandering oorboord gegooi word, moet die waarde van daardie gebruik eers vasgestel word. So 'n beproefde gebruik het gewoonlik baie meer waarde as wat sommer op die oppervlakte daarvan met die eerste oogopslag waargeneem kan word.

Baie van die kerk se tradisionele simbole word al meer onder die mikroskoop geplaas in die naam van vernuwing, lidmaatbevrediging en vol kerke. Oor liturgiese simbole, onder andere die toga, word daar deesdae baie vrae gevra. Wat is die waarde van hierdie simbole? Is die toga 'n uitgediende wêreldvreemde kleed, wat die kommunikasie van die Woord van God in die erediens belemmer of dra hierdie kleed van die dominee by tot die kommunikasie van die evangelie en het dit beslis nog 'n plek in die erediens?

Om hierdie vrae te beantwoord is dit noodsaaklik dat daar op wetenskaplik verantwoorde wyse, aan die hand van 'n prakties-teologiese metodologie, na te vors watter rol simbole, en spesifiek vir die doel van hierdie studie, die toga, in die kommunikasieproses van die erediens speel. As hipotese van hierdie ondersoek geld die vermoede dat liturgiese simbole, onder andere die toga, bydra tot die kommunikasie van die evangeliese boodskap. Hierdie hipotese sal in die ondersoek getoets word.

\section{METODOLOGIESE VERANTWOORDING}

Om op wetenskaplikheid aanspraak te maak is dit noodsaaklik dat daar, by die onderneming van 'n navorsingsprojek in die Praktiese Teologie, van 'n bepaalde metodologiese model gebruik gemaak sal word. In hierdie studie word die metodologiese model van Zerfass (1974:166) as basis gebruik om beweging tussen teorie en praxis te orden.

Zerfass beskryf die teorie-praxis verhouding as 'n bipolêre spanningsverhouding. Hierdie model van Zerfass word wyd binne die Praktiese Teologie erken en toegepas. Die model is maklik verstaanbaar en kan met groot sukses in die praktyk toegepas word (Heyns \& Pieterse 1990:38). Die kerk is geen onveranderlike grootheid nie, maar die liggaam van Christus. Die kerk is 'n lewende gemeenskap en dit veronderstel dinamiese groei. Die model van Zerfass gaan ook van hierdie standpunt uit en is gedurigdeur op soek na nuwe praktykteoriee, wat die kerk van Christus op 'n meer doeltreffende wyse kan dien. Om vanaf 'n bestaande praxis tot by 'n nuwe praxis te kom moet die teologiese oorlewering, ten grondslag van bestaande praktykteorieë, in die spanningsveld van die praxis van vandag gebring word. Hierdie praxis word empiriesanalities met behulp van die kennis van ander wetenskappe ondersoek, sodat 'n juiste 
beeld van die werklikheid verkry kan word (Heyns \& Pieterse 1990:39). 'n Nuwe prakties-teologiese teorie word gevorm vanuit 'n wisselwerking tussen die situasieanalise en die teologiese oorlewering. Hierdie prakties-teologiese teorie word dan 'n praktykteorie wat 'n nuwe praxis tot gevolg het. Die nuwe praxis word weer getoets aan beide die teologiese oorlewering en die situasie. Die moontlikheid bestaan dat hierdie toets daartoe kan lei dat die praktykteorie weer gewysig kan word (Heyns \& Pieterse 1990:40). Op hierdie manier ontstaan daar 'n nuwe praxis wat die teologiese oorlewering asook die nuwe situasie akkommodeer.

Met die eerste oogopslag lyk dit of hierdie model teologies begrond en wetenskaplik verantwoord is, maar Dreyer (1991:606) merk tereg dat nadere ondersoek die gebrekkige teologiese basis, waarop die model gebou is, ontbloot. In die model funksioneer die Skrif op dieselfde vlak as die teologiese oorlewering. Die Skrif is ook in hierdie model uitgelewer aan die aanspraak van die resultate van die empiriese analise. Louw wys ook op dié moontlike gevaar wat in die bipolêre model skuil. Die beginsel van bipolariteit werk met 'n korrelasiemoment wat in terme van die geloofskomponent in die verhouding God-mens rasioneel en dialogies geinterpreteer moet word. Sou hierdie korrelasiebeginsel ontologies geinterpreteer word, dreig die moontlikheid van 'n onhoudbare komplementariteit (Louw 1993:18). Hierdie bipolariteit kan lei tot die daarstelling van 'n wesenlike ooreenkoms tussen God en mens. Daarom is dit belangrik dat daar in 'n metodologiese model voorsiening gemaak moet word vir die onderskeid tussen die Skrif en die teologiese oorlewering. Die nuwe praktykteorie moet ten slotte binne die hermeneutiese spanningsveld van die Skrif getoets word. Slegs wanneer die nuwe praktykteorie hierdie toets kan deurstaan, kan dit in die kerk tot nuwe praxis lei. Daarom sal daar in die onderhawige studie hierdie belangrike insig van Dreyer bygewerk word by die metodologiese model van Zerfass.

Die aanpak van die studie sal, in die lig van die genoemde model, soos volg geskied: Ten eerste sal die praxis van kommunikatiewe handelinge asook die teoriee grondliggend hieraan analities-deskriptief ontleed word. Hierdie navorsing is van belang omdat die kerk binne hierdie praxis funksioneer, of te wel binne hierdie praxis is die kerk kerk. Die ontwikkeling in kommunikasieteorieë sal kortliks aangedui word asook die rol wat simbole in kommunikasie speel. Daar sal ook nagevors word watter rol spesifieke kleredrag by bepaalde geleenthede in kommunikasie speel. Grondliggende teologiese teorieẽ sal dan deduktief en histories-deskriptief ondersoek word. Die oorsprong van liturgiese simbole en ook die betekenis wat hulle vervul sal hieronder vasgestel word. Die sosiale en teologiese herkoms van die toga en ook die betekenis en die rol van die toga in die erediens, as simboliese kommunikasiemedium, sal nagevors word. 
In 'n tweede artikel sal die praxis en die teologiese teorieë in interaksie met mekaar gebring word, deur hulle krities-sinteties saam te voeg. Hieruit sal die moontlike daarstelling van 'n voorlopige praktykteorie na vore kom. Met die hulp van ander wetenskappe sal daar ook 'n stuk empiriese navorsing gedoen word om hierdie voorlopige teorie aan die praktyk van vandag te meet. Die gevoel van gemeentelede teenoor liturgiese simbole, spesifiek ook die toga, sal deur middel van 'n vraelys getoets word. Die vraelys sal cok poog om vas te stel of hierdie simbole 'n bydrae lewer tot kommunikasie in die erediens, of nie. Ten slotte sal daar 'n teologiese evaluering geskied deur die praktykteorie in die hermeneutiese spanningsveld van die Skrif te plaas. Hieruit sal die verstelde praktykteorie kom.

\section{DIE PRAXIS VAN KOMMUNIKATIEWE HANDELINGE EN TEORIEË}

\subsection{Die komplekse proses van kommunikasie}

Die woord kommunikasie is een van die sleutelwoorde in enige samelewing. Kommunikasie raak feitlik elke aspek van ons lewens. Sonder kommunikasie is daar chaos. Dink maar net aan die verhaal van die toring van Babel wat in Genesis 2 opgeteken staan. Daar was 'n warboel omdat die mense nie kon kommunikeer nie. Alles wat gedoen en gedink word, hou verband met kommunikasie: 'human beings literally live in a sea of communication' (Chartier 1981:12). Hierdie woord kommunikasie het 'n modewoord geword en daarmee saam het die essensie van die woord verflou. Maar die proses waarna hierdie woordjie verwys, is na regte uiters ingewikkeld en kompleks. Dit verbaas daarom nie dat sommiges daarna verwys as een van daardie wonderwerke wat steeds elke dag plaasvind nie. Kommunikasie behels veel meer as net die oordrag van woorde!

Juis as gevolg van die komplekse aard van kommunikasie is 'n definisie hiervoor moeilik te gee. "Communication refers to the act, by one or more persons of sending and receiving messages that are distorted by noise, occur within the context, have some effect, and provide some opportunity for feedback' (Devito 1988:4). Hierdie is maar een definisie, daar is nog talle. Daar bestaan geen enkele definisie wat omvattend genoeg of geskik is om die totale proses van kommunikasie te omskryf nie.

In 'n poging om hierdie ingewikkelde proses te verstaan is daar deur die gebruik van modelle en teorieë gepoog om 'n beter greep hierop te kry. Sokrates (469-399 v C), Plato (427-347 v C) en Aurelius Augustinus (354-430 n C) is maar 'n paar bekende name wat groot bydraes in hierdie verband gelewer het. Maar dit is Søren Kierkegaard wat beskou word as die grondlegger van die kommunikasiekunde van die twintigste eeu. Kierkegaard was 'n Christen wat in sy pogings om sy boodskap oor te dra, die problematiese aard van kommunikasie raakgesien het en dit dialekties so gekonseptuali- 
seer het dat hy sy godsdiensfilosofie vervat het in sy kommunikasieteorieë (Van Schoor 1986:68).

Kommunikasiemodelle en teorieë is met die verloop van tyd gewysig na gelang tekortkominge raakgasien en aanvullings en byvoegings gemaak is. 'n Ouer en 'n meer eenvoudige model is die liniêre model of die Shannon en Weaver model. Claude Shannon en Warren Weaver was twee telefooningenieurs wat hierdie model ontwikkel het (Frust, Vos \& Dreyer 1993:9). Die model sien kommunikasie as die oordrag van inligting vanaf 'n bron deur ' $n$ kanaal na 'n bestemming. Verder maak die model ook iets groot daarvan dat klank-, lawaai of ander steurniselemente die boodskap beinvloed. Al hierdie prikkels word gesamentlik na die ontvanger oorgedra. Dit is opmerklik dat hierdie model 'n eenrigtinggebeure impliseer (Huebsch 1983:43).

'n Groot deurbraak is gemaak toe daar besef is dat die kommunikasieproses meer behels as net 'n eenrigtinggebeure vanaf 'n sender na 'n ontvanger. Die ontvanger moet eers antwoord of verstaan of terugvoer voordat kommunikasie geskied het. Die begrip 'terugvoer' is deur ' $n$ man met die naam Nobert Wiener, ' $n$ tydgenoot van Shannon en Weaver, ontwikkel. Dit was deel van sy kibernetikateorie wat 'n algemene wetenskap van kommunikasie moes maak. Daar is besef dat kommunikasie nie langer as ' $n$ 'lyri' gesien kon word nie. Kommunikasie is eerder ' $n$ 'boog' of ' $n$ 'sirkel' as wat dit ' $n$ 'lyn' is Tubbs en Moss het afgewyk van die liniêre model deur die insluiting van 'terugvoer' in hulle model. Na die werk van Wiener het hulle besef dat terugvoer net so ' $n$ belangrike element in die kommunikasie is as enige ander element wat vroeèr geindentifiseer is (Frost et al 1993:12). Die sirkulêre kommuniksiemodel het die lig gesien. Die model word vandag nog gebruik; natuurlik het daar nog 'n klomp insigte bygekom en is daar nog talle ontdekkings oor hierdie wondergebeure gemaak.

Kommunikasie is gewoonlik kultuurgebonde. Die rede hiervoor is dat elke kultuur 'n eie simboliese universum besit (kyk Frost et al 1993:2). 'Met een symbolisch universum wordt bedoeld het geheel van voorstellingen, ervaringen, structuren die het beeld van de werklikheid van iemand vormen, waardoor hij ervaren kan en waardoor hij zich uitdrukken kan' (Van de Beek 1996:60). 'n Mens se simboliese universum word gevorm deur die kultuur en tradisie waarin hy opgroei. Van kleins af word ons simboliese universum gevorm. Hienuit dink ons en verstaan ons en kom ons tot 'n vergelyk. Van hieruit kommunikeer ons.

lets wat geweldig interessant in die kommunikasiegebeure is, is die verskynsel van nie-verbale kommunikasie. Navorsing het aangetoon dat van die totale kommunikasiegebeure, woorde slegs $55 \%$ bydra, die orige $45 \%$ word oorgedra deur middel van nieverbale faktore (Chartier 1981:83). Byna die helfte van dit wat ons kommunikeer word dus nie met woorde oorgedra nie, maar met byvoorbeeld oogkontak, liggaamshouding, 
gesigsuitdrukking, gebare, intonasie, ritme, stiltes, kleredrag, atmosfeer en relasie. 'n Mens sou kon sê dat verbale kommunikasie, kommunikasie is waar woorde as simbole gebruik word om objekte, gebeure en idees te verteenwoordig. Nie-verbale kommunikasie verwys na alle ander vorme van boodskapsoordrag. Chartier (1981:16) verdeel nie-verbale kommunikasie in vyf onderafdelings naamlik: gebare taal, aksietaal, objektaal, ruimte en tyd. Met gebaretaal bedoel hy kommunikasie met handgebare; aksietaal is die taal van liggaam, die sogenaamde body language of skeletklets; objektaal is die tentoonstelling van tasbare items byvoorbeeld kleredrag. Die tyd waarna hy verwys, het te make met punktuasie en kommatisering in spraak. Ruimte verwys na die plek waarin hierdie kommunikasie geskied en ook hoe hierdie plek ingerig is. As ons dus na iemand luister, is dit nie net sy of haar woorde wat op ons ore val, wat gaan bepaal wat ons verstaan nie, maar daar is talle ander nie-verbale faktore wat 'n rol speel in die oordrag van 'n boodskap.

Daar bestaan drie kategorieë waarbinne tekens in die kommunikasie van boodskappe funksioneer, naamlik: ikone, indekse en simbole. Ikone is tekens wat 'n sekere coreenkoms met die referente daarvan vertoon. So byvoorbeeld sal 'n prent, wat 'n presiese nabootsing is van dit wat afgebeeld word, die mees voor die hand liggende soort ikoon wees. Indekse is tekens wat 'n sekere assosiasie met die referente daarvan vertoon. 'n Voorbeeld hiervan is koors, want koors word daarmee geassosieer dat iets met 'n persoon se fisiologiese toestand verkeerd is. Die simbool is 'n teken waarvan die verhouding tussen die teken en die referent op konvensie berus. Simbole vertoon geen oreenkoms in vorm met hulle referente nie en daar is geen direkte assosiasie tussen simbole en hul referente nie. 'n Voorbeeld hiervan is die vis wat 'n simbool van die vroeë kerk was (Botha 1990:96).

\subsection{Simbole en kommunikasie}

Simboolkommunikasie is van groot belang en dit dra groot krag in kommunikasie. Sonder simbole kan mense en hulle gemeenskappe nie funksioneer nie. Dit is deel van die hele kommunikasiepatroon tussen mense. 'Sonder simbole kan ons nie lewe nie, want hulle vorm ten slotte die realiteit van ons bestaan' (Holz 1981:54).

Maar wat is 'n simbool presies? Die woord kom vanuit die Griekse taal. Die Griekse woord symbolon beteken merk, teken of etiket. Daar is reeds verduidelik wat Botha onder 'n simbool verstaan, maar soos die begrip kommunikasie kan daar ook nooit een allesomvattende definisie hiervoor gegee word nie. Tog vat die definisie wat in The Interpreter's Dictionary of the Bible aangegee word, op bondige wyse, 'n groot deel van hierdie woord se betekenis vas. 'A representation visual or conceptual, of that which is unseen and invisible' (Kooy 1990). 'n Simbool bestaan uit twee elemente. 
Eerstens die kenelement (signifies, significant) wat iets aandui of verteenwoordig. Hierdie kenelement is 'n sinlik waarneembare ding, persoon, houding, teken en ook 'n gesproke woord. Die onsigbare, geestelike, transendente en abstrakte dinge of realiteite, word deur die sintuiglik waameembare kenelement voorgestel. Dit wat voorgestel word, is die tweede element van 'n simbool, die aangeduide, betekende, bo-sinlike werklikheid (signified, signifié). 'n Simbool ontstaan waar die konkrete, sigbare, die aanduidende en die geestelike, onsigbare realiteite, die aangeduide, met mekaar verbind word. Die kenelement en die onkenbare realiteit word byeengebring (Barnard 1994: 181).

Simbole is so deel van ons lewe dat ons nie werklik besef watter uitwerking hulle op ons het nie. Deur simbole word die mens bewus van die dieper dinge wat 'n mens nie op die opperviakte waarneem nie. Simbole is kragtige kommunikasiemiddels. Hulle spreek die hele persoon aan. By simbole gaan dit om 'n direk, nie-rasionele kommunikasie met 'n ander werklikneid. Die waarneming is intuitief en raak die hele persoon, met sy affektiwiteit en sy sintuie (Barnard 1994: 88).

Die filosoof Paul Ricoeur (1987:249) het daarop gewys dat die die krag van simbole onder meer in die onthulling van die meervoudige betekenis van waaruit verbeelding groei, bestaan. Simbole het nie net 'n onthullende funksie nie, maar ook 'n verhullende funksie. Simbole gaan teen die positiwistiese oortuiging in dat die werklikheid ontdek kan word (Wright 1988:140). So is daar altyd 'n element van misterie rondom simbole. Hierdie struktuur van dubbele betekenis vereis 'n interpretasie wat prinsipieel sop en onuitputlik is. Die simbool wek nie net denke nie, maar lei ook tot verstaan. As rede hiervoor geld dat simbole begrip daarstel en tegelykertyd voorkom dit verwarring en wanvoorstelling (Biehl 1991:149).

Eers in die eeu waarin ons ons tans bevind, het daar psigologiese teorieë oor die simbool na vore gekom; veral uit die werke van Sigmund Freud (1856-1939) en Carl Gustav Jung (1875-1961). Freud het sy teorieë oor die, wyse waarop mense hulle persepsies van die veriede verwring, misplaas, kondenseer en filtreer (volgens die inwendige bewustelike en onbewustelike dinamika van die psige), gebaseer op die droomsimbool om só neurotiese versteurings as die fundamentele data te analiseer. Jung het simbole nie alleen as private simptome van onopgeloste onderdrukking gesien nie, maar ook as uitdrukkings van die psige se stryd om verwesenliking en individualisering (kyk Heisig 1987). Ook het Jung simbole gesien as vitaal belangrike brûe tussen die bewuste en die onbewuste. Simbole voorsien foci waardeur voorbewustelike verlange, vrese en gevoelens geartikuleer en georden word. Om sonder simbole te probeer leef is om die mens te reduseer tot een vlak van verstandelike bewustheid (Thiselton 1972). 
Simbole praat. Hulle informeer, hulle lê uit, hulle wys aan en hulle waarsku. Simbole dien as sigbare herkenningstekens. Mense herken op grond van simbole mekaar as lede van 'n bepaalde gemeenskap en van 'n bepaalde oortuiging en as geloofsgenote. Hulle druk cenheid uit, is gemeenskapstigtend en samebindend, hulle gee betekenis aan die lewe. Juis omdat simbole herkenningstekens is en gemeenskapstigtend is, werk hulle mee om aan die lewe van mense sin en betekenis te gee (Barnard 1994:183).

\subsection{Die kormmunikasiekrag van kleredrag}

Soos vroeêr gemeld, is kleredrag ook 'n nie-verbale element wat bydra tot die kommunikasiegebeure. Klere is so alledaags - ons dra dit immers elke dag - daarom is ons nie bewrus daarvan en besef ons nie wat se kragdadige kommunikasiemiddels klere is nie. Daar is beslis baie dinamiek in ' $n$ voël se vere. Klere bedek nie net ons liggame en beskerm ons nie net teen wind en weer nie. Op 'n byna onbewustelike wyse praat hierdie simbole ook met ons. Hulle kommunikeer, hulle vertel altyd iets van hulle draer. Die kommunikasiekrag van 'n spesifieke kledingstuk by 'n spesifieke geleentheid kan nooit geringgeskat word nie. 'It is impossible to wear clothes without transmitting social signals. Every costume tells a story, often a very subtle one, about its wearer' (Morris 1977:213).

Dink maar hoe trek ons aan wanneer ons vir 'n werksonderhoud moet gaan. Jy trek jou beste pak klere aan, want jy wil mos net jou beste voetjie voor sit. Hierdie spesiale pak klere 'praat' met die persoon wat die onderhoud voer. Die pak klere kan selfs die knoop deurhaak en die skaal na jou kant toe laat swaai sodat jy die werk kry. Aan die ander kant sou die pak klere negatief ervaar word by 'n informele sosiale geleentheid saam met vriende. Daar sal selfs vir jou gevra word 'Hoekom lyk jy so styf?'

Die lys van moontlike betekenisse wat deur klere gekommunikeer kan word, is oneindig lank. Klere kan byvoorbeeld iets sê van 'n persoon se ouderdom, se gesiag, se sosiale klas of posisie en ook van sy of haar godsdiens. Deur middel van klere sê mense altyd meer as wat hulle met hulle mond sê. 'As kommunikasiemiddel of simbool is kleredrag uiters geskik' (Van Schalkwyk 1990:17).

Daar word in die algemeen twee hooffunksies van kleding onderskei, naamlik vormfunksies en betekenisfunksies. By vormfunksies gaan dit oor liggaamsmodifikasies en liggaamstoevoegings, hetsy vir gemak of gerief of beskerming teen natuurelemente en by sommige kultuurgroepe beskerming teen bonatuurlike magte. Die betekenisfunksies van klere het te make met dit wat klere kommunikeer. Kleding kommunikeer iets van mense se identiteit, hulle gemoedstemming, hulle gesindheid, hulle kennis of geleerdheid, hulle persoonlike vaardighede en ook iets van hulle lewensbeskouing. Dit bepaal hoe mense beleef en behandel gaan word deur ander, want kleding dra 'n 
bepaalde persepsie van hulle draer oor aan ander. Klere dra altyd 'n boodskap oor wat of positief of negatief geinterpreteer en ervaar kan word deur hoorders. 'Ultimately the meanings communicated by objectively discernible types and properties of dress depend on each person's subjective interpretation of them' (Roach-Higgins \& Eicher 1992:15). Soos alle simbole is kleding ook kultuurgebonde. Daarom sal kledingstukke verskillende boodskappe in verskillende kultuurgroepe kommunikeer - 'the meanings that a person attributes to various outward characteristics of dress are based on his/her socialization within a particular cultural context' (Roach-Higgins \& Eicher 1992:15).

'n Besondere funksie van kleredrag as kommunikasiemiddel is dat dit aangewend kan word as teken van groepsidentiteit, byvoorbeeld volks- of nasionaledrag, militêre uniforms en ook religieuse drag. So dien klere as herkenningstekens van verskillende groepe en kommunikeer dit 'n eenheidsgevoel. Deur die dra van spesifieke kleredrag, erken die individu sy of haar identiteit as behorende tot ' $n$ besondere groep mense, en word sodoende van ander groepe onderskei.

Die simboliek van kleur speel by klere ' $n$ baie groot rol - kleure funksioneer self ook as simbole. So is swart klere byvoorbeeld onder andere simbool van rou in die Westerse samelewing. Dit is ook die kleur van duisternis, boosheid en die dood. Dit het die kleur geword wat met toorkuns geassosieer word en vandaar die benaming swart kuns (black art). Daarom is die Duiwel en dié se trawante deur die vroeë Christene as swart voorgestel. Maar swart is ook gebruik as simbool van 'n ander soort sterwe, naamlik die afsterwe van ydelheid, plesier en rykỏomme van hierdie wêreld. Daarom het verskeie godsdienstige ordes in die vroeë Christendom swart kledingstukke gedra. Onder die askete, wat in die kloosters woonagtig was, het swart ook simbool van reinheid en nederigheid geword (Konteks 1994:17).

\section{BESTAANDE TEOLOGIESE TEORIË̈}

\subsection{Liturgiesiese simbole}

In reaksie op die oordrewe simboliek en die praalagtige aard van die Rooms-Katolieke liturgiee het die Calvinistiese reformatore eerder vir 'n simbool-arme liturgie gekies (Van der Merwe 1997:13). Dit is te verstane en ons is terdeë bly dat hierdie hervorming in die erediens plaasgevind het. Die Woord moet sentraal staan en in die RoomsKatolieke erediens is die Woord beslis verdring deur oordrewe simboliek en nog talle ander spandabelrighede. Maar dit wil nie sê dat daar nie plek vir simbole in ons erediens is nie, en dit wil ook nie sê dat die Gereformeerde liturgie sonder simboliese betekenis is nie. 
Soos wat kommunikasie 'n sleutelwoord is vir die samelewing, is dit ook natuurlik vanselfsprekend dat kommunikasie vir die kerk 'n sleutelwoord is. Die kerk is 'n lewende kommunikasiegemeenskap (Van Wyk 1982:24). Die kerk het immers met die kommunikasie van God met die mens, God se lewende Woord, te doen. Die woord evangelie impliseer al reeds kommunikasie van een of ander aard (Van der Merwe 1997:7). Vanweë die konsentrasie op die Woord het die Reformatoriese kerk alle rede om op kommunikasie te konsentreer.

Die erediens is 'n kommunikatiewe gebeurtenis. Hierdie kommunikasie is in die cerste plek Woordkommunikasie (Beukes 1994:145). in die Reformatoriese erediens staan die Woord sentraal. Daar moenie allerhande uitspattighede in die erediens wees wat die klem van die Woord kan afhaal nie. 'Die Woord het vlees geword en onder ons kom woon' (Joh 1:14). Hierdie Woord is nou in ons en dit moet gespreek word, ons moet hierdie Woord verkondig en dit moet sentraal staan in die liturgie; hierdie Woord moet gekommunikeer word. Maar daar moet altyd onthou word dat dit in kommunikasie om meer gaan as net woorde wat iemand spreek, en wat op iemand anders se ore val. Daar is nog talle ander faktore wat 'n rol speel in kommunikasie. Talle faktore kan daartoe bydra dat hierdie Woord beter gehoor kan word.

Daar is reeds daarop gewys dat simbole groot kommunikasiekrag het. Liturgiese simbole se krag om die Woord te kommunikeer, moet daarom nie vergeet word nie. ' $\ldots$ they are basic to all human experience and are the foundation stone of Christian liturgy, which to all intents and purposes is made up of symbolic actions' (Lebon 1987: 1). Stafford (1962:28) skryf ook: 'From the earliest time the eye-gate has been an important entrance to the soul of man.'

Naas die woord-taal as medium van kommunikasie ken die liturgie ook 'n taal sonder woorde. Hierdie taal is die wêreld van tekens wat 'n bepaalde werklikheid aandui. In die liturgie vind kommunikasie nie net deur gesproke woorde plaas nie, daar is ook sinlik waarneembare dinge, handelinge, houdings en persone wat bo hulleself uitwys na ander onsigbare realiteite. Beelde en simbole is 'n onmisbare onderdeel van mensiike kommunikasie, daarom kan dit nie gemis word in die kommunikasie van geestelike waarhede en werklikhede tussen God en mens er. tussen mense onderling nie (Barnard 1994:179). As ons, wat nietige mense is, oor die almagtige God praat, bestaan daar buitendien nie menslike woorde wat God toereikend kan beskryf nie. Ons kan maar net in simboliese taal praat cor God. Dat die taal waarin ons God verstaan, uitspreek en oproep, alleen maar simboletaal kan wees, besef elkeen van ons terdee (Cromphout 1978:56).

In die erediens speel simboliese handelinge en simbole 'n besondere groot rol. Dit was haas die geval vanaf die begin van die Christelike eredienste, deur die lang eeve 
heen en vandag weer op 'n geintensiveerde wyse (Barnard 1994:195). Vir die vroeé Christene was simbole essensieel. Simbole is baie aangewend en het baie prominent gefunksioneer in die geloofslewe van hierdie mense. Vroeë Christelike geskrifte borrel oor van simbole en van simboliese taal - vergelyk maar die Openbaring van Johannes. Hierdie is maar een voorbeeld van vroee Christelike literatuur vol simboliek. Die vis, die kruis, die skaap, die duif, die boom, die herder, die anker, die monogram, die pou en nog talle meer was alles simbole in die vroeë Christelike gemeenskap gewees en het 'n groot rol in hierdie gemeenskap vervul. Tydens die erediens is daar 'n verskeidenheid van simbole wat 'n groot impak het. Hierdie simbole skep atmosfeer en hulle verkondig. Dink maar aan die simboliese tekens en handelinge in die doop en die nagmaal, tydens die gebruik van hierdie sakramente. Die nagmaaltafel, die doopvont, die water, die brood, die wyn, die beker, die breek van die brood, die fisiese besprinkeling en alles wat deel uitmaak van hierdie sakramente is propvol simboliek, wat boekdele spreek. Die kerkgebou warin die liturgiese gebeure plaasvind, is ook 'n simbool. Die feit dat hierdie gebou anders as ander geboue lyk, sê iets. Hierdie gebou het 'n toring, 'n klok en 'n weerhaan, wat 'n kerkgebou onderskei, aspekte waarvan elkeen iets simboliseer. Baie kerke het as deel van die argitektoniese ontwerp 'n kruis, die Christusmonogram en ook verskillende kanselklede, wat ook iets simboliseer (Vos \& Pieterse 1997:85). Die preekstoel, die kateder, die groot kanselbybel, die kerksang en musiek, die plasing van kerkraadslede, die kerklike drag van gemeentelede en van die liturg het alles simboliese waarde wat sekere boodskappe kommunikeer. Hierdie simbole plaas die Woord, waarom dit primêr in die erediens moet gaan, in 'n raampie sodat hierdie Woord beter 'gehoor' kan word. Daarom mag die 'dekor' waarteen die Woord in die erediens verkondig word, nie gering geskat word nie.

\subsection{Die toga en ander kerklike kleredrag}

Die Rooms-Katolieke, Griekse en Anglikaanse kerke heg groot waarde aan die gewaad van die liturg. So skryf die Rooms-Katolieke Kerk byvoorbeeld noukeurig aan sy ampsdraers voor watter ampsgewade hulle moet dra. Die hiërargie kom tot uitdrukking in die verskillende kledingstukke wat deur die priester, biskop, kardinaal en pous gedra word (Smal 1970:96). In hierdie studiestuk word daar nie in detail hierop ingegaan nie.

Op 9 Oktober 1524 het Luther sy monnikegewaad vir goed uitgetrek. Daarvandaan het hy altyd in sy doktorstoga (die woord toga is afgelei van die Latynse werkwoord tego $=$ bedek) op die kansel en die kateder verskyn (Pont 1984:98).

Die kleding van die geestelikes het 'n lang en ryke geskiedenis. In die Ou Testament is die klere wat ampsdraers gedra het, as van besondere belang beskou. God gee 
nie net self opdrag dat bepaalde klere deur ampsdraers gedra moet word nie, maar skryf ook in detail voor hoe hierdie klere moet lyk (Eks 28 - kyk Beukes 1993:6). In die Nuwe Testament lyk dit of ampsdraers steeds Ou-Testamentiese ampsdrag gedra het; so het Johannes die Doper byvoorbeeld 'n mantel gedra (Matt 3:4; Mark 1:6) en ook die priesters het besondere klere in hierdie tyd gedra (Luk 20:46 - kyk Beukes 1993:9).

Die Griekse filosowe het 'n pallium (tipe mantel) gedra wanneer hulle onderrig gegee het. Die Griekssprekende kerkvader, Justinus die Martelaar circa 165 n C), wat vir 'n lang tydperk 'n student in die filosofie was, voordat hy 'n Christen geword het, het sy 'filosoofmantel' bly dra, nadat hy bekeer is, terwyl hy die Christelike geloof geproklameer het (Brown 1969:13). Dit wil voorkom of daar tot en met die 6e eeu geen onderskeid in die kleredrag van die ampsdraers en van die gewone lidmate was nie. Die Apostoliese Constitutiones, wat uit 375 n $\mathrm{C}$ dateer, meld dat ' $\mathrm{n}$ biskop die eucharistie clad in splendid raiment moet gebruik. Dit beteken dat hy aan die nagmaal met sy sunday best moet deelneem (Down 1982:347). Die biskop het dus sy beste klere aangetrek wanneer hy aan die nagmaal deelgeneem het.

In die eerste eeu is die toga virilis by spesiale geleenthede deur die senaat gedra. Hierdie besondere drag van die eerste eeu het ' $n$ meer alledaagse drag in die tweede eeu geword. Die hoèr klas het die toga virilis met die linea vervang. Hierdie was 'n kledingstuk wat die hele liggaam van die nek toi enkels bedek het. 'n Tuniek is bo-oor hierdie kleed gedra wat tot op die kniee gehang het. Die paenula, ook genoem die lacerma, is by formele geleenthede deur mans en vrouens bo-oor hulle ander klere gedra (Beukes 1994:140). Daar bestaan 'n bekende skets van pous Gregorius die Grote en sy ouers, wat uit ongeveer $600 \mathrm{n} C$ dateer. Die enigste verskil in die kleredrag van die pous en dié van sy ouers in hierdie skets, is geleê in die feit dat die pous 'n pallium gedra het. Hierdie pallium was 'n lang serp en dit was waarskynlik die eerste onderskeidende kledingstuk wat deur geestelikes in die kerk gedra is (Beukes 1994:140).

Gedurende die Middeleeue was dit die algemene tendens dat al die ampsdraers die deftige drag uit die vorige eeu gedra het. Dit was die algemene gebruik dat die geestelikes bestaande deftige burgerlike drag in die erediens gedra het, soos al die ander mense van daardie bepaalde tyd. Wanneer die modes verander het, het die geestelikes die bestaande kleed bly dra. Hierdie kleed is dan met die verloop van tyd as ampskleed beskou (Barnard 1997). Ook hierin moet die oorsprong van die toga gesoek word. Die toga se oorsprong kom vanuit die Romeinse modes. Dit was 'n soort bokleed wat booor ander klere gedra is (Die Kerkbode 1992:4). Die clerus wou hulle van die leke onderskei en het dit ook met hulle kleredrag gedoen. Om hierdie rede het die kleredrag van die ampsdraers met verloop van tyd 'n simbool van kerklike hiërargie geword. 
Daar het wrewel teen die ampsdraer en sy gewaad ontstaan. Daarom het die verset teen die kerklike hiërargie ook verset teen die ampsdraers se kleredrag meegebring (Beukes 1994:142).

Gedurende die tyd van die Hervorming was die koorrok die algemene drag van gegradueerde persone aan universiteite. Die koorrok, wat ook die priesterrok genoem is, was algemene drag van enige persoon wat onderrig gegee het. Dit was 'n aanduiding dat die persoon bevoeg was om onderrig te gee (Beukes 1994:142). Luther, Calvyn en ook nog ander Hervormers het hierdie priesterrok, wat vandag die toga genoem word, gedra. 'Luther zelf verscheen den 9 October 1524 het eerst zonder monnikskap in een priesterrok, waarvoor de keurvorst zelf hem de stof had gegeven, in de kerk' (Scholten 1856:211). Toe Luther se gesag om die Woord te verkondig, later deur Rome betwis is, het hy die akademiese toga van die inrigting waar hy studeer het, aangetrek. Die toga het gedien as uiterlike bewys van sy bevoegdheid en opleiding om te kan preek (Die Hervormer 1983:10).

Die bef bet uit sierlike hempskrae ontwikkel (Scholten 1856:222). Die ontwikkeling het uit die Italiaanse en Spaanse kraag gekom (Barnard 1997). Die gebruik hiervan in die kerk dateer uit die veertiende eeu toe die pous en ander hooggeplaastes begin het om allerlei deftige hempskrae te dra. In die sestiende eeu is die bef veral deur Duitse predikante en regsgeleerdes tydens amptelike geleenthede gedra. In die sewentiende eeu was die bef algemene drag van aansienlike persone gewees (Beukes 1994: 143).

Daar was in Suid-Afrika aanvanklik geen sprake van ampsdrag in die kerk gewees nie. Foto's en sketse dui egter daarop dat predikante oral in die alledaagse deftige drag met 'n toga of mantel en bef gekleed gegaan het. Met die koms van die Skotse predikante na Suid-Afrika in die negentiende eeu het die Skotse toga ook na Suid-Afrika gekom (Beukes 1994:144). Tot en met die Algemene Kerkvergadering van 1970 het die predikante van die Nederduitsch Hervormde van Afrika 'n toga en 'n bef gedra. Saam met die bef het sommige predikante ook 'n strikdas gedra. Die ou Hollandse toga was die algemeenste toga, aangesien die meeste predikante van Holland afkomstig was (Beukes 1994:144). Die Algemene Kerkvergadering het soos volg oor die toga besluit: "Aangesien die toga uitdrukking is van die akademiese bevoegdheid om die evangelie te verkondig en die besondere werk te doen, beveel die vergadering aan dat die toga die akademiese toga sal wees van die plek waar die persoon studeer het' (NHKA 1970:103). Tot en met 1983 was die bef en die toga verpligtend gewees vir predikante om te dra tydens eredienste, maar in 1983 het die Algemene Kerkvergadering besluit: 'dat die dra van 'n bef en strikkie al dan nie, oorgelaat sal word aan die diskresie van die draers' (NHKA 1983:26). 
Die Reformatore het aan die predikante in die kerke van die Hervorming geen voorskrifte gegee ten opsigte kerklike kleredrag nie. Daar is aan elke leraar die vryheid gegee om self te besluit hoe hy hom sou klee (Smal 1970:96). Daar was in elke geval 'n verset teen die Rooms-Katolieke ampsgewaad. In die kerk van die Nuwe Verbond was daar geen plek vir 'n seremoniële ampsgewaad nie (Smal 1970:97). Ook in reaksie teen die hiërargie in die Rooms-Katolieke Kerk het die Reformatore swaar klem gelê op die gedagte dat die gemeente die liggaam van Christus is waarin almal gelyk is en was daar geen plek vir hiërargiese ampsgewaad nie (Beukes 1994:141).

In die tyd van die Hervorming is die toga gedra om te dien as uiterlike bewys van die akademiese bevoegdheid om die Woord te verkondig. Vandag dien die toga in die Afrikaanse Reformatoriese kerke steeds as aanduiding van die akademiese kwalifikatiwat die predikant behaal het en is geen ampsdrag nie. Dit was die oorspronklike doel wat die toga vir die Reformatore moes vervul. Maar intussen het hierdie simbool, die toga, saam met die kerk van die Reformasie 'n lang pad geloop. Verwys hierdie simbool nie vandag dalk na meer as net na 'n akademiese bevoegdheid vir die mense van die kerk nie?

Hierdie simbool het saam met die liturgie en die gemeente gegroei en sê vandag meer as net iets oor akademiese bekwaamheid. Dit wat die toga kommunikeer, hang natuurlik af van mens tot mens. 'The preacher who wears a robe communicates high uppitiness to some; for others, the preacher wearing a business suit fails to have an appropriate sense and feel for worship and liturgy. He is much too casual, they say' (Chartier 1981:85). Die toga is deel van die liturgie en dit maak as simbool 'n belangrike deel uit as bydraende faktor tot erediens belewing.

Daar bestaan 'n verskeidenheid van standpunte oor kerklike kleredrag en spesifiek ook oor die toga. Sommiges is van mening dat die kerk as geheel moet wegdoen met ampsdrag. Hierdie mense reken dat litugiese drag, vir gewone mense 'n teken van afstand en wêreldvreemdheid is. Die toga is 'n 'doodbiddersgewaad' wat afstand skep tussen die predikant en die gemeentelede (Lekkerkerker 1971:179). Daar word gereken dat ampsdrag ' $n$ negatiewe Rooms-Katolieke oorblyfsel is. 'Ampsdrag is 'n teken dat die kerk nog nie ten volle daarin geslaag het om die verskil tussen die ampte en leke te oorbrug nie' (Beukes 1994:144). Die handhawing van ampsdrag of besondere drag vir ampsdraers word beskou as 'n miskenning van die dienswerk van die gewone lidmate (Houda 1991:539).

Vir sekeres is die drag van die predikant 'n totaal onbelangrike saak. Dreyer in (Die Hervormer 1970:9) skryf dat die argument dat die toga die bewys van diè predikant se akademiese kwalifikasie is, wel histories juis mag wees, maar sê dat dit in ons tyd geen sin het nie. "n Argitek dra nie 'n besondere soort jas om daarmee aan te dui 
dat hy as argitek bekwaam is nie. Dieselfde geld vir die ander akademiese opleidings ... 'n Mens loop nie, veral nie in die kerk nie, sy akademiese kwalifikasies en rondswaai nie'.

Muller (1987:12) is van mening dat die toga 'n beeld van wêreldvreemdheid en somberheid uitstraal. Hy noem die toga 'n wêreldvreemde kleed en vra die vraag of hierdie wêreldvreemde kleed van dominees nie dalk mede-verantwoordelik daarvoor is dat nie slegs hulle persoon nie, maar ook hulle boodskap al deur baie afgeskryf word as iets bo-wêrelds en abstrak; iets wat nie met die gewone dinge van die lewe te doen het nie? 'Die stywe atmosfeer in ons eredienste, die hoë taalgebruik en vreemde klere kan maklik die boodskap van God se betrokkenheid by hierdie lewe belemmer' (Muller 1987:9). Daar is selfs dié wat reken dat die Nuwe Testament en Jesus self ook afwysend teenoor enige vorm van ampsdrag staan (Barnard 1997). Lukas 2:46 word as stawing vir hierdie argument gebruik (Beukes 1994:139).

Aan die ander kant is daar dié wat liturgiese drag positief ag. 'Daar kan beslis 'n baie sterk punt daarvoor uitgemaak word dat ons te alle tye moet let op die kleredrag wat ons na die eredienste toe aantrek. Ons eerbied en respek teenoor die kerk en ons eredienste hang beslis nie in die eerste plek af van ons kleredrag of haarstyl nie, maar allereers van die gesindheid in ons harte. As ons gesindheid teenoor God reg is, sal ons respek ook deur ons kleredrag getoon word' (Die Hervormer 1988:2). 'Ter wille van goeie orde mag die waardigheid van die diens van God deur die besondere ampte nooit in gedrang kom deur kleredrag wat onvanpas is nie' (Die Kerkbode 1987:9). Die toga word verdedig dat dit as uitdrukking van die objektiwiteit van die verkondiging dien. Die toga is die uitdrukking van die ondergeskikmaking van die predikant se indi vidualiteit aan die amp van die verkondiging (Lekkerkerker 1971:179). Nog argumente ten gunste van die toga is dat die toga deel van ons Reformatoriese erfenis uitmaak, en cok dat predikante die toga moet dra as teken daarvan dat hulle bevoeg is om die Woord te kan verkondig.

Vir diegene wat so sterk voel oor liturgiese drag is dit belangrik dat veral die bedienaar van die Woord op die kansel sal verskyn met 'n duidelike onderskeidsteken. Sommiges soos Cooper (1988:35) meen dat sekere liturgiese klere, onder andere die toga, 'are at the same time biblical, traditional and distinctly Reformed'. Daar is selfs dié wat dit as ' $n$.Bybelse verpligting (Eks $28: 2,43$ ) ag dat predikante met ' $n$ 'heilige kleed' beklee sal wees wanneer hulle hulle ampswerk in die erediens vervul (Die Kerkbode 1992:4).

Daar het onlangs ' $n$ koerantartikel van prof P G J Meiring van die Nederduitse Gereformeerde Kerk verskyn met die opskrif: 'Gaan haal die toga weer uit die kas!' Hierin maak Meiring die uitspraak dat hy nogal jaloers is op die kerke in ons land wat 
deur al die jare ampsdrag vir hulle ampsdraers gehandhaaf het. Die redes wat hy hiervoor aanvoer, is dat ampsdrag die predikant herkenbaar maak en dat dit voordele inhou vir die pastoraat. Sy belangrikste argument was dat dit liturgies sin maak dat 'n dominee, veral wanneer hy of sy as voorganger in die erediens optree, soos 'n dominee sal lyk. Hy maak verder die uitspraak dat die vervlakking in ons eredienste deur die dra van ' $n$ toga beveg kan word en dat die gereformeerde karakter van kerkdienste op die wyse behou sal word. Meiring vra hom ook self die vraag af of daar nie belangriker sake is as ampsdrag om oor te besin op pad na die jaar tweeduisend toe nie. Hy verwys dan na die geval in 1917 waar die sinode van die Russies-Ortodokse Kerk dae lank geredeneer het oor die kleur van die liturgiese tossel, wat in die kerk gedra moes word. Maar hy merk op dat dit oor meer gaan as net 'n tossel. Dit gaan daaroor dat die liturg Sondae in die kerk sy of haar werk met doeltreffendheid moet verrig (Die Kerkbode 1997:10). Meiring skryf dat hy onlangs genooi is om as verteenwoordiger van die Nederduits Gereformeerde Kerk by die bevestiging van die nuwe Anglikaanse deken van Pretoria teenwoordig te wees. Hy sê dat hoewel hy 'n nuwe pak en rooi das aangehad het, het hy soos 'n seer vinger uitgestaan tussen al die dominees, biskoppe en priesters, almal deftig en korrek, as verteenwoordigers van hulle denominasies met hulle kerklike drag, geklee.

Oor die kleur van die toga is daar ook al swaarde gekruis. In die Rooms-Katolieke Kerk het die priesters wit kledingstukke gedra. Die Protestantisme en met name die Hervormde Kerk het deftige swart daarteenoor gestel (Almanak 1946:43). Die swart kleur van die toga is vir sommige nie aanvaarbaar nie. 'Het komt my voor, dat voor het levensbesef van veel mensen in onze huidige tijd deze gitzswarte dracht vreemd aan doet. Het doet begrafenisachtig aan (Lekkerkerker 1958:115). In die Nederduitse Gereformeerde Kerk is die dra van 'n toga deesdae weer opvallend, maar op sommige plekke nie net as die oorspronklike swart toga nie, maar as 'n toga met 'n bont stola wat pas by die kerklike jaar. Daar verskyn selfs blou togas met silwer kruise daarop (Die Kerkbode 1997:9).

\subsection{Die verlies aan simbole}

Mense leef in en uit die verwysingskrag en kommunikasie van simbole. Simbole verskaf identiteit en geborgenheid. 'Some of the most creative thinkers in the twentieth century have been at great pains to warn us that we should care for our symbolism as we care for our mental and spiritual health' (Sagovsky 1978:4). Behalwe vir die unieke situasie waarin Afrikaners hulle tans bevind en waarin hulle hulle mees fundamentele kulturele simbole verloor het, is daar nog 'n algemene aanslag op die verlies van simbole in die moderne denkwêreld waarvan hulle deel is (Vos \& Pieterse 1997: 
84). As gevolg van die aanslag van die rasionalisme en die aggressiewe aanwending van tegnologie verloor mense talle simbole en word hulle simbool-arm (Sagovsky 1978:3).

Daar is nog altyd in die Reformatoriese eredienste nie veel klem op die simbole in die erediens geplaas nie, juis in reaksie teen die oordrewe klem wat die Rooms-Katolieke Kerk daarop geplaas het. In die onsekere tyd waarin mense hulle tans bevind, waar simbole wegval, soek gemeentelede na vashouplekke, geborgenheid en identiteit in hulle godsdiens. Simbole kan in hierdie tyd lei tot nuwe ervarings van die teenwoordigheid, genade en verlossing van God (Vos \& Pieterse 1997:84). Die Aufklarung het die neiging tot intellektuele kommunikasie versterk. Dit het tot ' $n$ verskraling van die mens gelei. Die affektiewe en konatiewe dimensies van die mens is afgeskeep, terwyl die kognitiewe dimensie oorbeklemtoon is. Hierdie geringskatting van die ander dimensies van menswees het ook in die erediens deurgewerk, sodat mense se behoefte om hulle gevoelens simbolies uit te druk en op die vlak van simboliek te kommunikeer, geignoreer is (Strauss 1995:87).

Die feit dat die mens van vandag in 'n oorgangstyd leef, maak dit noodsaaklik dat rituele en simbole as kommunikasie-aanvulling onder die primaat van die Woord in die erediens moet dien vir die ontmoeting met God (Burger 1995:75). Die paradigmaskuif vanaf die moderne na die postmoderne era is tans aan die gebeur en nog lank nie voltooi nie. Mense bevind hulle teenswoordig in hierdie oorgangstyd. In 'n oorgangsfase het die vaste reëls en ordes van die vorige fase verval en is die mens besig om nuwe reëls en strukture te ontwikkel. In hierdie fase is die ervaring van verlies en onsekerheid baie sterk. Die behoefte by mense aan simbole is in so 'n fase baie sterk (Vos \& Pieterse 1997:87).

Lidmate van die Reformatoriese Afrikaanse kerke beleef nou 'n tyd van ongeborgenheid, identiteitsoeke en onsekerheid. In hierdie tyd is simbole van onskatbare waarde. Die Afrikaanse kerke het vir lank die klem op die regte leer en die kognitiewe onderskrywing van die waarheid waarin gelowiges glo, gelê. Daardeur het die emosionele kant, die beleweniskant en die kontak met die geheimeniskant van God minder klem gekry. Dit is jammer, want die gemeentelid is nie net 'n rasionele wese nie. Deur ook die emosionele kant van gemeentelede aan te raak, kan dit bydra tot meer effektiewe verkondiging van die Woord van God (Vos \& Pieterse 1997:84).

'n Belangrike dimensie van die postmoderne reaksie op die modernistiese rasionaliteit raak juis die eng en beperkende opvatting van die mens as kommunikatiewe subjek. In die postmodernisme word die beperkende antropologiese denke van die era van die moderniteit teengewerk deur 'n wyer antropologiese opvatting. Die klem word nou gelê op gevoel en selfs die nie-rasionele kant van die mens as kommunikatiewe wese 
(Steenkamp 1996:756). Simbole spreek die multidimensionele mens aan (Depoortere 1987:11). Hulle kommunikeer op die kognitiewe sowel as die affektiewe vlak van die mens (Adam 1985:70).

Strauss (1995:88) wys daarop dat die mens van vandag deur televisie, videos en rekenaars omvorm is tot ' $n$ wese wat ingestel is op die visuele. Daarom moet die estetiese sy van die erediens uitgebou word. Simbole het hier 'n reuse rol te speel. Die mens in die erediens het nie net spirituele behoeftes nie, maar ook fisiese, emosionele en estetiese behoeftes. Hierdie behoeftes word aangespreek deur die gebruikmaking van simboliek in die erediens (Vos \& Pieterse 1997:84). Die kommunikatiewe krag van simbole lê juis opgesluit in die feit dat hulle na wêrelde verwys wat buite die sigbare werklikheid bestaan. Hulle funksioneer as vensters wat 'n uitsig gee op die oneindige, die onuitspreeklike en die transendente. Simbole reageer op die soeke en die behoefte van die individu en die gemeente aan iets diepers, aan dit wat anderkant hierdie werklikheid lê. 'n Werklikheid waarvoor daar nie woorde bestaan nie, word op 'n sinvolle wyse as onuitspreeklike werklikheid deur die funksie van simbole aan die gemeente gekommunikeer (Otto 1982:125).

\subsection{Die atmosfeer en die 'andersheid' van die erediens}

Die versoeking kan groot wees om vroom te sê dat die skepping van atmosfeer in die erediens die werk van die Heilige Gees is en dat die liturg en die gemeente dit van God moet afbid en verwag. Maar wat die atmosfeer in die erediens betref, mag die werk van die Heilige Gees nie as alibi vir luiheid en swak beplanning gebruik word nie (Muller 1990:29). Die erediens is nie net bloot 'n menslike byeenkoms nie. God is self daar teenwoordig. Die aard van die erediens kan met twee begrippe weergegee word, naamlik ontmoeting en .viering. In die erediens kom God en ontmoet die gemeente en die gemeente ontmoet God in feesvierende blydskap. Die Almagtige word ontmoet en daarom is 'n ligte, speelse atmosfeer onvanpas. Die heiligheid van God word in die erediens betree. Wat in die erediens ook al gebeur, gebeur coram Deo, in die teenwoordigheid van God. Die geestelike lewe mag nooit met geestelike jolyt verwar word nie, daarom is ' $n$ jolige atmosfeer met familiêre verwysings na God vreemd aan die aard wan die erediens. Die erediens moet egter ook 'n feeskarakter hê waarin God met blydskap gedien kan word. Hierdie viering moet egter met ontsag getemper word (vgl Muller 1990:31). Die bekende godsdiensfenomenoloog en taalkenner, Rudolf Otto, het die term die 'gansandere God' gebruik as uitdrukking van die begrip 'die onbekende God' (kyk Van Aarde 1995:18). Teenoor die religieuse optimisme van die Liberale Teologie en die opvatting oor 'n kameraadskap tussen God en mens, het Karl Barth (1886-1968) die gansandersheid van God gestel (kyk Pelser 1994:37). God is die soe- 
wereine God en nie 'n mens nie; God is die Gansandere. Mense moet hulle plek ken. 'Onbekend is God en onbekend sal God bly' (Barth 1967:59). God is so groot dat die mens God nie uit eie vermoë kan ken nie. Dit is slegs wanneer God Godself aan die mens openbaar dat die mens iets van God kan ken. Hierdie verhewendheid en andersheid van God behoort in die liturgie gesimboliseer te word. God is anders as die mense en die mense se wêreld.

Die erediens met die liturgie is 'n unieke vindplek van kontak met God en God se heil. Dit is waar die gelowige vergiffenis en verlossing, genesing, liefde en inspirasie meegedeel word, en die teenwoordigheid van God ervaar word. Die verslae, verlore hopelose mens van ons dag vind heil in die erediens, want in die erediens heers daar 'n unieke atmosfeer en vind daar ' $n$ unieke gebeure plaas wat nêrens anders in die wêreld ervaar kan word nie. Sodra mense in 'n erediens instap moet hulle die ervaring hê dat hier iets totaal anders aan die gang is as op enige ander plek - iets totaal anders as wat elke dag in die wêreld daarbuite plaasvind. 'n Erediens is iets anders as ' $n$ ander of 'n gewone wêreldse byeenkoms - hier word God ontmoet (Vos \& Pieterse 1997:84). Hierdie andersheid van die erediens skep by die gelowige 'n verwagting en 'n gemoedstemming - die gelowige kom in die stemming van ontvanklikheid vir die Woord van God. Hierin het liturgiese simbole 'n groot bydrae te lewer. Hulle dra daartoe by dat hierdie verwagting en gemoedstemming geskep word; hulle skep 'n atmosfeer wat die erediens onderskei van enige ander wêreldbyeenkoms en hulle sê iets van God se nabyheid. Die erediens moet ' $n$ vreemde gebeurtenis wees. Daarom moet die atmosfeer in die erediens uniek wees, anders as dié van 'n konsert, pawiljoen, teater of volksfees (Muller 1990:31). Bonislaw Malinowsky (1884-1942), wat groot bydrae op die gebied van die godsdienssosiologie gelewer het, het dit gestel dat daar 'n duidelike onderskeid tussen die sakrale en die profane in enige gemeenskap is. Godsdiens verteenwoordig 'n ander gedragsidioom as die gewone daaglikse (Van der Merwe 1997:22).

\subsection{Vernuwing?}

Daar word kort-kort die standpunt gehoor dat die etos van die Nederduitsch Hervormde Kerk nie meer vir die jeug en die mense van vandag aanvaarbaar is nie. Stemme word gehoor dat die liturgie van die Nederduitsch Hervormde Kerk 'n totale verandering sal moet ondergaan (Konteks 1995:48). Verandering is goed. 'Verandering, aanpassing of vernuwing is net so noodsaaklik as die handhawing van tradisionele waardes' (Van der Merwe 1997:28). Die kerk van Jesus is geen statiese en onveranderlike grootheid nie (Laubsher 1987:57). Inteendeel die kerk is die liggaam van Christus en dit impliseer dat die kerk ' $n$ lewende organisme is en dit veronderstel voortdurende dinamiese groei 'na Christus toe.' In die kerk bestaan daar 'n spanning tussen konstantheid en variasie, 
tussen stabiliteit en veranderlikheid, want die kerk is tegelykertyd instituut en organisme (Laubsher 1987:57).

Die kerk bestaan immers uit mense wat in Christus nuwe mense is ( 2 Kor 5:17), maar terselfdertyd ook nog steeds sondaarmense simul iustus et peccator. Soos die bestaan van die individuele Christen, is die bestaan van die kerk ook 'n dialektiese bestaan. Die kerk moet dus al meer word wat hy reeds in Christus is (Laubscher 1987: 59). Dit vra vir ' $n$ volgehoue proses van vernuwing.

Erediensvernuwing impliseer 'n hartgrondige bekering (metanoia) van die gemeente (Strydom 1994:264). Ongelukkig word eredienste deesdae meermale misverstaan as eredienspopularisering. Alles om net mense in die kerke te kry. Eredienste word 'lekker' gemaak vir gemeentelede, die horisontale word oorbeklemtoon ten koste van die vertikale dimensie. Die proklamasie van die Woord van God word 'n geselsie oor 'aktuele onderwerpe'. Die sekularisasie wat buite in die wêreld aan die gebeur is word ook in die erediens ingedra. Mense is vry, hulle behoeftes moet bevredig word, hulle is die spil waarom alles draai. Hierin word daar natuurlik legio humanistiese klanke gehoor. Die nuutste aanbiddingseksperimente, lofprysingsbenaderings, musiekmodes, -style, -tegnieke en liturgiese danse word sondermeer in die liturgiese praktyk betrek - solank as dit die mense 'laat kerk toe kom.' Verantwoorde gebruike en style word goedsmoeds oorboord gegooi as synde niksseggend uitgedien en outyds (Strydom 1994:265).

Van 'n hartgrondige liturgiese metanoia (bekering) is daar myns insiens nie sprake nie - daar vind in werklikheid 'n liturgiese slopingsproses plaas. Die erediens word 'n sekularistiese 'happening.' Die volk van God se liturgiese viering van die Christusgebeure word vervang met 'n weliswaar vroom, maar horisontalistiese 'celebration' en waaroor gaain die 'celebration'? 'Too often ... one had the impression that little more was celebrated than being young and healthy and having a guitar' (Grant 1986:9). Ons moet oppas dat ons nie die erediens wil vernuwe om mense te trek nie. Dit gaan nie in die erediens om die bevrediging van die mense nie. Egte Bybels gefundeerde erediensvernuwing gaan nie primêr van die mens uit nie, maar van God Drie-enig (Strydom 1994:264).

Juis in hierdie tye waar daar gereeld gehoor word dat die etos van die Hervormde Kerk nie meer aanvaarbaar is nie skryf die wereldbekende evangeliese Lutherse teoloog, Wolfhart Pannenberg (1992:23) dat net die Rooms-Katolieke, Oosters-Ortodokse en Evangeliese Protestantse kerk die cen-en-twintigste ceu sal oorleef. Die rede hiervoor is dat die ander kerke onseker is oor hulle geloof en identiteit. Dit kom daarop neer dat baie kerke al vanweé sekularisme, maar net geword het soos alle ander instellings in die wêreld en dat dit in toenemende mate sal vermeerder. Die gees van verwereldliking, geestelike leegheid en identiteitloosheid het die meeste kerke oorspoel. Daar bestaan geen twyfel nie dat ontkerstening, verwelreldiking en humanisering die 
Christelike godsdiens aan aantrekkingskrag en geloofwaardigheid laat inboet het. Pannenberg waarsku dat die hoofstroom kerke sal verdwyn indien hulle al meer en meer opgaan in die droom van 'n Babiloniese vrederyk. Ware Christene sal gryp na gemeenskappe waar identiteit en antwoorde op die leegheid van die wêreld te vinde is (Beeld, bl 8).

\section{KONKLUSIE}

Die voorafgaande verkenning van teorie en praxis stel die navorser voor die uitdaging om deur middel van hierdie interaksie nuwe 'byderwetse' en teologies-verantwoorde praktykteoriee te poneer. Dit is duidelik dat kommunikasie 'n uiters komplekse proses is waarin simbole, onder andere klere, ' $n$ kardinale deel uitmaak. So ook in die liturgie vervul simbole 'n onvervangbare funksie in die kommunikasie van die woord van God. Mag ons dit durf waag om hierdie kosbaarheid van liturgiese simbole te verkwansel vir 'truuks' en 'foefies' en dit net om ter wille van vernuwing mense te trek? En dit terwyl ons op die lang duur eerder mense uit die kerk sal sien verdwyn, omdat hierdie byeenkomste nie iets vergestalt van God se teenwoordigheid nie, maar eerder net so ankerloos en leøg lyk soos die wêreld daarbuite ...

\section{Literatuurverwysings}

Adam, A 1985. Wo sich Gottes Volk versammelt. Freiburg: Herder.

Almanak van die Nederduitsch Herwormde Kerk van Afrika 1946. Oor 'n vroeëre predikantekleredrag, bl 43.

Bamard, A C 1997. Plaas Christus en die Woord sentraal in die erediens en in die bediening - nie die ampskleed nie. Ongepubliseerde manuskrip geskryf vir Die Kerkbode).

Barnard, A C 1994. In die kragveld van die Woord en die Gees. Pretoria: Outeur.

Barth, K [1922] 1967. Der Romerbrief. Zehnter Abdruk der neuen Bearbeitung. Zürich: EVZ-Verlag.

Beeld 14 Maart 1995. Kerke sal verdwyn: Indien geestelike leegheid toeneem, bl 8.

Beukes, M J du P 1994. Erediens, 2. Pretoria: Kital.

—_ 1993. Liturgiese klere met besondere verwysing na die Nederduitsch Hervormde Kerk van Afrika. HTS 49, 5-18.

Biehl, P 1991. Symbole geben zu verstehen: Zur praktisch-theologischen Bedeutung der Symbolhermeneutik Paul Ricoeurs, in Praktisch-Theologisch Hermeneutik: Ansăzze-Anregungen-Aufgaben. Reinbach: CMZ-Verlag.

Botha, J 1990. Semeion. Pretoria: NG Kerkboekhandel.

Brown, C 1969. Philosophy and the Christian faith. London: Billing \& Sons.

Burger, C 1995. Gemeentes in transito. Kaapstad: Lux Verbi. 
Chartier, M R 1981. Preaching as communication: An interpersonal perspective. Nashville: Abingdon.

Cooper, D J C 1988. Vesture: A Reformed perspective. RefLitM 22, 33-36.

Cromphout, F 1978. De taal waarin wij God verstaan. $\pi i 1 / 2$.

Depoortere, K 1987. Geen leven zonder symbolen. $T L i 1 / 2$.

Devito, J A 1988. Human communication: The basic course. New York: Harper \& Row.

Die Herwormer April 1983. Betekenis van die amp in inhoud en nie kleredrag, bl 10.

Die Herwormer Augustus 1970. Besluite van die Algemene Kerkvergadering, bl 9.

Die Herwormer September 1983. Waardigheid in lewe, nie kleredrag, bl 9.

Die Kerkbode Januarie 1992. Wat het tog van die toga geword ...?, bl 4.

Die Kerkbode Augustus 1997. Gaan haal die toga uit die kas!, bl 10.

Die Kerkbode Augustus 1997. Van pikkewynpak na bont stola, bl 9.

Die Kenkbode September 1987. Kerklike ampsdrag is 'n vorm van uitgediende mode, bl 9.

Down, M 1982. The costume of the clergy. Theol 85, 346-353.

Dreyer, T F J 1991. Eerste tree in die Praktiese Teologie - waarheen? HTS 47, 597-608.

Frost, R, Vos, H \& Dreyer, M 1993. Kommunikasie dinamiek. Isando: Lexicon Uitgewers.

Grant, J W 1986. The hymn as theological statement. The Hymn 36/4, 7-10.

Heisig, J W 1987. s v Symbolism. The Encyclopedia of Religion.

Heyns, L M \& Pieterse, H J C 1990. Eerste treě in die Praktiese Teologie. Pretoria: Gnosis Boeke.

Holz, R 1981. Religion-Symbolhandlung-Sakrament. Liturgisches Jahrbuch.

Houda, R W 1991. Clerical gab - an ambigious sign? Worship 56, 537-540.

Huebsch, J C 1983. Kommunikasie 2000. Pretoria: Sigma-Pers.

Konteks. April 1994. Christelike simbole - Kleure, bl 16.

Konteks Mei 1995. Ons Hervormde etos?, bl 48.

Kooy, V H 1990. s v Symbol. IDB.

Laubsher, J A 1987. Vastheid en variasie binne die liturgiese ordes van die Nederduitse Gereformeerde Kerk. DD-proefskrif, Universiteit van Pretoria.

Lebon, J 1987. How to understand the liturgy. London: SCM.

Lekkerkerker, A F N 1958. Nogmaals een gesprek over de toga. KED 13/2, 113-121.

Lekkerkerker, A F N 1971. Oorsprong en funksie van het amp. 's Gravenhage: Boekencentrum N.V.

Louw, D J 1993. Pastoraat as ontmoeting: Ontwerp vir 'n basisteorie, antropologie, metode en antropologie. Pretoria: Sigma-Pers.

Morris, D 1977. Manwatching: A field guide to human behaviour. London: Cape. 
Muller, J 1987. Vastheid, variasie en kreatiwiteit in die liturgie. Praktiese Teologie in Suid-Afrika 3.

1990. Die erediens as fees. Pretoria: NG Kerkboekhandel.

Nederduitsch Hervormde Kerk van Afrika $s$ a. Wetten \& Bepalingen. Pretoria: NHKA.

1970. Notules Algemene Kerkvergadering. Pretoria: NHKA.

1983. Notules Algemene Kerkvergadering. Pretoria: NHKA.

Otto, G 1982. Predigt als Sprache. TPT 17, 117-127.

Pannenberg, W 1994. Christianity and the West: Ambiguous past, uncertain future. First Things 48, 18-23.

Pelser, G M M 1994. Hermeneutiek: Vanaf die vroegste kerk tot by die nuwe hermeneutiek. Ongepubliseerde studiehandleiding, Departement Nuwe-Testamentiese Wetenskap (Afd A), Universiteit van Pretoria.

Pont, A D 1984. 'n Man van die Woord - Martin Luther. Pretoria: Kital.

Ricoeur, P 1987. Erzählung, Metapher und Interpretationstheorie. ZThK, 232-253.

Roach-Higgins, M E \& Eicher, J B 1992. Dress and identity. Clothing and Textiles Research Journal 10/4, 1-8.

Sagovsky, N 1978. Liturgy and Symbolism. Bramcote Notts: Grove Books.

Scholten, G D J 1856. Kerklijke en wereldlijke kleding, de toga, mantel en bef. 'sGravenhage: Noordendorp.

Smal, P J N 1970. Die kerklike kleed. NGTT 11/2, 96-109.

Stafford, T A 1962. Christian symbolism in the evangelical churches. Nashville: Abingon.

Steenkamp, L J S 1996. Kerk en kultuur in 'n postmoderne samelewing. HTS 52, 746-764.

Steyn, A G W et al 1994. Moderne statistiek vir die praktyk. Pretoria: Van Schaik.

Studente Herwormer, bylaag tot Die Hervormer Junie 1988. Kleredrag in die erediens, bl 2.

Strauss, M U 1995. Eerste treë in die ontwerp van 'n gereformeerde liturgiese simboliek. Theolgia Acta 15/2, 86-95.

Strydom, W M L 1994. Sing nuwe sange, nuutgebore: Liturgie en Lied. Bloemfontein: NG Sendingpers.

Temmingh, H 1997/09/24. 'n Gesprek met die departementshoof van die musiekdepartement van die Universiteit van Pretoria.

Thiselton, A C 1972. s v Sign, Symbol. A New Dictionary of Liturgy \& Worship.

Van Aarde, A G 1989. Hand 7:48 - 'Die Allerheiligste woon nie in mensgemaakte konstruksies nie ....': Die relevansie van die Nune-Testamentiese wetenskap na aanleiding van die metafoor 'tempel'. Pretoria: Van Schaik. 
Van Aarde, A G 1995. Kerk en teologie op pad na die derde millennium: ' $n$ Paradigmatiese verskuiwing van middelmatige aard. HTS 51, 13-37.

Van de Beek, A 1996. Schepping: De wereld als voorspel voor de eeuwigheid. Baarn: Callenbach.

Van der Merwe, P J 1997. Fenomene, aktualiteite en tendense wat kerk en teologie raak. Ongepubliseerde studiehandleiding Departement Godsdiens- en Sendingwetenskap (Afd A), Universiteit van Pretoria.

- 1997. Teologiese Godsdiensfilosofie. Ongepubliseerde studiehandleiding Departement Godsdiens- en Sendingwetenskap (Afd A), Universiteit van Pretoria.

Van Schalkwyk, J A 1990. Visuele kommunikasiemiddele: Die kleredrag van die Molepo. S A Tydskrif vir Kultuurgeskiedenis 3/2, 17-24.

Van Schoor, M 1986. Wat is kommunikasie? Pretoria: Van Schaik.

Van Wyk, J A 1982. Inwoning: God se Woord in menslike kommunikasie, in Cronjé, J M \& Van Wyk, J A (samests), Van mens tot mens: Kerklike kommunikasie in teorie enpraktyk, 1-105. Pretoria: NG Kerkboekhandel.

Vos, C J A \& Pieterse, H J C 1997. Hoe lieflik is $U$ moning. Pretoria: RGN.

Wright, T R 1988. Theology and literature. London: Blackwell.

Zerfass, R 1974. Praktische Theologie als Handlungswissenschaft: Praktische Theologie heute. München: Kaiser. 